\title{
Enhancement of viral production by addition of nitrogen or nitrogen plus carbon in subtropical surface waters of the South Pacific
}

\author{
Chiaki Motegi, Toshi Nagata* \\ Center for Ecological Research, Kyoto University, 2-509-3 Hirano, Otsu, Shiga 520-2113, Japan
}

\begin{abstract}
We tested the hypothesis that viral production is limited by nutrient availability in oligotrophic subtropical surface waters of the South Pacific. Nutrient (C, N, P) addition experiments were conducted at 2 stations (Stn SX18, 39 $60^{\prime} \mathrm{S}, 169^{\circ} 60^{\prime} \mathrm{W}_{\text {; }} \mathrm{Stn} \mathrm{SX22}, 19^{\circ} 60^{\prime} \mathrm{S}, 169^{\circ} 60^{\prime} \mathrm{W}$ ) to examine the responses of viral production $\left({ }^{3} \mathrm{H}\right.$-thymidine incorporation) and related variables in bottlecontained surface waters. At Stn SX18, viral production was enhanced in bottles amended with $\mathrm{N}$ and $\mathrm{C}$ with concomitant increases in bacterial production and growth, suggesting that both viral and bacterial production were co-limited by $\mathrm{N}$ and C. At Stn SX22, additions of $\mathrm{N}$ accelerated viral production with no consistent response of bacterial production, which might be an indication that prophage production was induced due to the alleviation in $\mathrm{N}$ limitation of host bacteria. In both experiments, nutrient-induced increases in viral production were not accompanied by increases in viral abundance, suggesting a possibility that viral production was balanced by loss. Our results suggest that viral production is limited by the availability of $\mathrm{N}$ or $\mathrm{N}+\mathrm{C}$ in subtropical waters of the South Pacific, implying that viruses affect the mode of nutrient-induced changes in bacterial production and microbial trophic transfers in oligotrophic oceanic waters.
\end{abstract}

KEY WORDS: Viruses $\cdot$ Viral production $\cdot$ Nutrient limitation · Oligotrophic surface waters $\cdot$ South Pacific subtropical gyre

\section{INTRODUCTION}

Lytic viral production and associated destruction of host bacterial cells account for a large fraction (10 to $50 \%$ ) of bacterial mortality in various aquatic environments, playing an important role in controls of bacterial communities, food webs, and biogeochemical cycling (Fuhrman 1999, Wilhelm \& Suttle 1999, Weinbauer 2004). Previous studies have found that additions of nutrients stimulate lytic viral production in estuarine (Hewson et al. 2001), coastal (Tuomi et al. 1995, Wilson et al. 1998), neritic (Williamson \& Paul 2004), and freshwater (Weinbauer et al. 2003, Lymer \& Vrede 2006) environments, leading to the proposition that the enhancement of the production of host bacteria due to the alleviation of nutrient limitation results in increased viral production. Factors that account for this response in viral production may include increased encounter probability between host and viruses (density-dependent effect, Thingstad 2000), increased host activity (growth-dependent effect, Middelboe 2000), and induction of prophage production due to alterations in the metabolic status of the lysogenic host (lysogenic decision effect, Williamson et al. 2002). Enhancement of lytic viral production in response to nutrient additions has important implications for aquatic ecosystems, since it results in reduced transfer efficiency of bacterial production to higher trophic levels (Fuhrman 1999, Wilhelm \& Suttle 1999). However, little is known about how viral populations respond to nutrient additions in oligotrophic open waters of subtropical gyres, the largest oceanic domain on earth, where bacterial growth is limited by carbon and nutrient availability 
(Carlson \& Ducklow 1996, Cherrier et al. 1996, Rivkin \& Anderson 1997).

Previous studies conducted in coastal and neritic waters have suggested that $\mathrm{P}$ availability limits lytic viral production; these studies include investigations conducted in the Gulf of Mexico (Williamson \& Paul 2004) and the Raunefjorden (Tuomi et al. 1995, Wilson et al. 1998). These results might be explained by the high nucleic acid to protein ratio (hence high $\mathrm{P}: \mathrm{N}$ ) of viruses (Bratbak et al. 1993). However, C and N can also limit viral production depending on the environment (Tuomi \& Kuuppo 1999, Williamson \& Paul 2004). Stoichiometric constraints on viral production have yet to be fully clarified (Wikner et al. 1993). To our knowledge, no previous studies have examined the responses of viral production to $\mathrm{P}, \mathrm{N}$, and $\mathrm{C}$ additions for a complete set of single or combined additions of a suite of nutrients, making it difficult to assess which element limits (or co-limits) lytic viral production.

Here we tested the hypothesis that viral production is limited by nutrient availability in the subtropical gyre of the South Pacific. This region is characterized by low chlorophyll (chl) a concentrations and low primary productivity (Longhurst 1998), with few data available on processes mediated by bacteria and viruses. We conducted nutrient addition assays using surface waters and found that $\mathrm{N}$ or $\mathrm{N}+\mathrm{C}$ additions enhance viral production with coupled or uncoupled responses of bacterial production and growth.

\section{MATERIALS AND METHODS}

Study site, sample collection, and experimental setup. Sample waters were collected at 2 stations deployed in the South Pacific (Stn SX18: 39 $60^{\prime} \mathrm{S}$, $169^{\circ} 60^{\prime} \mathrm{W}_{\text {; }}$ Stn SX22: $19^{\circ} 60^{\prime} \mathrm{S}, 169^{\circ} 60^{\prime} \mathrm{W}$ ) during a cruise by RV 'Hakuho-Maru' (KH 04-5) between January and February 2005. The sampling stations are located in the South Pacific Subtropical Gyre (SPSG) Province, although Stn SX18 is close to the convergence zone (Longhurst 1998). Surface water samples were collected with a clean bucket, filtered through $150 \mu \mathrm{m}$ nylon mesh to eliminate large plankton, and contained in $20 \mathrm{l}$ polyethylene tanks. One liter each of the filtrate was dispensed into polycarbonate bottles (1 l capacity, Nalgene). Either $\mathrm{P}\left(\mathrm{NaH}_{2} \mathrm{PO}_{4}\right), \mathrm{N}$ $\left(\mathrm{NH}_{4} \mathrm{Cl}\right)$, or $\mathrm{C}$ (glucose) was added alone or in combination to sample waters in order to obtain a complete set of sole or combined additions of elements $(P, N, C$, $\mathrm{P}+\mathrm{C}, \mathrm{P}+\mathrm{N}, \mathrm{N}+\mathrm{C}, \mathrm{P}+\mathrm{N}+\mathrm{C}$, and a non-addition control) with a fully replicated ( 3 bottles for each treatment) factorial design. The final concentration of each compound added was $1 \mu \mathrm{M}$. The bottles were incubated for $24 \mathrm{~h}$ at in situ temperature in the dark. The bucket, tanks, nylon mesh, and bottles used for the experiments were rinsed before use with $10 \%$ hydrochloric acid followed by vigorous rinsing with Milli-Q water. During sample collection and handling, gloves were worn and care was taken to minimize contamination. However, a clean bench and metalfree reagents to minimize trace metal contamination were not used in this study. Potential effects of trace metals (e.g. iron) on viral production and bacterial activities (Church et al. 2000) were outside the scope of this study.

Abundances of bacteria and viruses. For the determination of bacteria and viral abundances, subsamples were withdrawn from original sample waters and from incubation bottles at the end of incubation. Subsamples were preserved with $0.2 \mu \mathrm{m}$ filtered paraformaldehyde (final concentration $2 \%$ ), stored in a refrigerator, and used for the preparation of slides according to Noble (2001). Slides were prepared within $12 \mathrm{~h}$ after sampling. Triplicate slides were prepared for each bottle. Two $\mathrm{ml}$ of samples were filtered through a $0.02 \mu \mathrm{m}$ Anodisc filter (Whatman), followed by rinsing with $0.02 \mu \mathrm{m}$ filtered Milli-Q water. Filters were placed on $100 \mu \mathrm{l}$ of SYBR Green I solution (Molecular Probes, final dilution $2.5 \times 10^{-3}$ ), and stained for $15 \mathrm{~min}$ in the dark. After staining, excess dye was removed with Kimwipes (Kimberly-Clark). The filters were then mounted with an anti-fade mounting solution (4:1 mixture of AF-1, Citifluor, and VectaShield, Vector Labs) to be stored frozen until later analysis. Bacteria and viruses were counted using an epifluoresence microscope (Olympus BX61; filter U-MWIB2) equipped with a $100 \mathrm{~W}$ Hg lamp (HSH-1030L). At least 300 cells of bacteria and 200 virus-like particles, distinguished on the basis of shape and brightness (Noble \& Fuhrman 1998), were counted for each slide. The coefficient of variation (CV) for triplicate slides was 1 to $10 \%$ and 1 to $17 \%$ for bacterial abundance and viral abundance, respectively.

Bacterial production. Bacterial production was determined from the incorporation rate of thymidine (TdR) using a centrifuge method (Kirchman 2001). Triplicate subsamples $(1.5 \mathrm{ml}$, contained in screwcapped centrifuge tubes, SSI) and 1 trichloroacetic acid (TCA)-killed control were amended with [methyl- $\left.{ }^{3} \mathrm{H}\right]$ TdR (89 $\mathrm{Ci} \mathrm{mmol}^{-1}$, Amersham, TRK686, final concentration $10 \mathrm{nM}$ ) to be incubated for 12 to $17 \mathrm{~h}$ at in situ temperature in the dark. Extraction by precipitations with $5 \%$ cold TCA was followed by cold ethanol rinsing using a temperature controlled desktop centrifuge $\left(18000 \times g\right.$ at $4^{\circ} \mathrm{C}$ for $10 \mathrm{~min}$ for each run; Eppendorf, 5417R). The extracts were then completely dried and mixed with scintillation cocktail $(1 \mathrm{ml}$, Ultima Gold, Packard Instruments) for the radioassay using a Wallac 1400 scintillation counter with cor- 
rections for quenching. The $\mathrm{CVs}$ of the triplicate measurement were 1 to $42 \%$.

Viral production. Viral production was determined by the TdR method with enzyme digestions according to Noble \& Steward (2001) with modifications. Triplicate subsamples $(7 \mathrm{ml}$ each) were contained in polypropylene tubes (14 ml capacity, BD Falcon), amended with [methyl- $\left.{ }^{3} \mathrm{H}\right] \mathrm{TdR}\left(89 \mathrm{Ci} \mathrm{mmol}{ }^{-1}\right.$, Amersham, TRK686, final concentration $10 \mathrm{nM}$ ), and incubated for $24 \mathrm{~h}$ at in situ temperature in the dark. The incubation was terminated by filtering the samples through $0.2 \mu \mathrm{m}$ syringe filters (Acrodisc, Pall). Triplicate filtrates $(1.5 \mathrm{ml}$ each) were contained in screw-capped mircocentrifuge tubes ( $2 \mathrm{ml}$ capacity, SSI) to be incubated (room temperature for $1 \mathrm{~h}$ ) with a mixture of nucleases (1 U DNase I [Sigma, D5025], 1 U RNase A [Sigma, R4875], and 5 U Micrococcal nuclease [Worthington, NFCP] $\mu^{-1}$ ). After incubation, samples were heated $\left(100^{\circ} \mathrm{C}, 1 \mathrm{~min}\right)$ to denature the enzymes, followed by cooling for $10 \mathrm{~min}$ on ice. In order to hydrolyze viral capsids and bacteria-derived protein, which might be non-specifically radiolabeled because of TdR catabolism (Brittain \& Karl 1990), we treated the samples with Proteinase $\mathrm{K}\left(100 \mathrm{\mu g} \mathrm{ml}^{-1}\right.$ final concentration, Sigma, P2308, $37^{\circ} \mathrm{C}$ for $\left.1 \mathrm{~h}\right)$. After heating $\left(100^{\circ} \mathrm{C}\right.$ for $1 \mathrm{~min}$ ) and cooling (on ice for $10 \mathrm{~min}$ ), each sample was spiked with $40 \mu \mathrm{l}$ of a carrier solution $\left(50 \mu \mathrm{g} \mathrm{ml}^{-1}\right.$ final concentration each of DNA [Sigma, D4522], RNA [Sigma, D4522], and BSA [Sigma, B4287]) and $80 \mu \mathrm{l}$ of ice-cold $100 \%$ TCA. Precipitates were collected by centrifugation $\left(18000 \times g\right.$ at $4^{\circ} \mathrm{C}$ for $10 \mathrm{~min}_{i}$ Eppendorf, 5417R), resuspended in ice-cold 5\% TCA, and extracted again by centrifugation. The precipitates were then hydrolyzed with $50 \mu \mathrm{l}$ of $5 \%$ TCA at $90^{\circ} \mathrm{C}$ for $30 \mathrm{~min}$. After cooling, $1 \mathrm{ml}$ of scintillation cocktail (Ultima Gold, Packard Instruments) was added to each tube for the radioassay (see above). TCA-killed controls were prepared for each treatment. However, because of high variability in radioactivity of TCAkilled controls, a fixed value (40 dpm) was used as a blank for all treatments. Ratios of radioactivity of sample to blank generally exceeded 7 . The CVs of triplicate measurements were 2 to $49 \%$.

Abundance of heterotrophic nanoflagellates. Abundances of heterotrophic nanoflagellates (HNF) in original sample waters were counted according to Sherr \& Sherr (1983). Subsamples $(50 \mathrm{ml})$, fixed with glutaraldehyde (final concentration $2 \%$ ), were doublestained with 4',6-diamidino-2-phenylindole (DAPI) and fluorescein isothiocyanate (FITC). Cells were collected on $0.8 \mu \mathrm{m}$ black Nucleopore filters (Whatman) and counted under an epifluoresence microscope (Olympus BX61; filters used were U-MWU2 and UMWIB2 for DAPI and FITC, respectively).

\section{RESULTS}

\section{Environmental and microbial variables}

At the time of our sampling, surface water temperature and salinity at Stn SX18 were $17.2^{\circ} \mathrm{C}$ and 35.0 PSU, respectively, whereas corresponding values at Stn SX22 were $28.6^{\circ} \mathrm{C}$ and 35.1 PSU (Table 1). The low concentrations of chl a $\left(0.10 \mu \mathrm{g} \mathrm{l}^{-1}\right.$, and $0.09 \mu \mathrm{g} \mathrm{l^{-1 }}$ for Stns SX18 and SX22, respectively) and nitrate $\left(<0.01 \mu \mathrm{mol} \mathrm{l}^{-1}\right.$ for both stations) in surface waters that we collected (Table 1) are typical for the SPSG Province (Longhurst 1998).

Bacterial production rates (TdR incorporation rates) were $9.6 \pm 0.6$ and $13.0 \pm 0.9 \mathrm{pmol} \mathrm{TdR} \mathrm{l}^{-1} \mathrm{~d}^{-1}$ at Stns SX18 and SX22, respectively. These values are close to the range of the TdR incorporation rates determined in other subtropical regions (e.g. Hoppe et al. 2006). Viral production determined from TdR incorporation varied in the range of $0.2 \pm 0.1 \mathrm{pmol} \mathrm{TdR}^{-1} \mathrm{~d}^{-1}$ (Stn SX18)

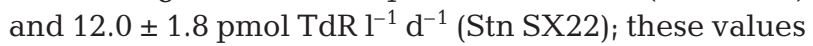
fall within a range of viral incorporation rates of TdR reported in other marine systems, including coastal and high latitude oceanic regions (Steward et al. 1996, Helton et al. 2005). Other chemical and biotic variables are summarized in Table 1.

Table 1. Physical, chemical, and microbiological variables at the sampling stations. Errors are \pm SD $(n=3)$. The data of temperature, salinity, nutrient concentrations, and chl a concentrations are from the cruise report of the KH04-5 cruise (Ocean Research Institute, The University of Tokyo). HNF: heterotrophic nanoflagellates

\begin{tabular}{|c|c|c|c|c|c|c|c|c|c|c|}
\hline $\begin{array}{l}\text { Stn } \\
\text { (location; } \\
\text { date) }\end{array}$ & $\begin{array}{c}\text { Temp. } \\
\left({ }^{\circ} \mathrm{C}\right)\end{array}$ & $\begin{array}{c}\text { Salinity } \\
\text { (PSU) }\end{array}$ & $\begin{array}{c}\mathrm{PO}_{4}{ }^{3-} \\
(\mu \mathrm{M})\end{array}$ & $\begin{array}{l}\mathrm{NO}_{3} \\
(\mu \mathrm{M})\end{array}$ & $\begin{array}{c}\text { Chl a } \\
\left(\mu g l^{-1}\right)\end{array}$ & $\begin{array}{c}\text { Bacterial } \\
\text { abundance } \\
\left(\times 10^{8}\right. \\
\left.\text { cells } 1^{-1}\right)\end{array}$ & 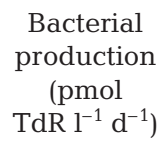 & $\begin{array}{l}\text { Viral } \\
\text { abundance } \\
\left(\times 10^{8}\right. \\
\left.\text { viruses } 1^{-1}\right)\end{array}$ & 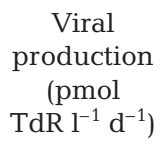 & $\begin{array}{c}\text { HNF } \\
\text { abundance } \\
(\text { cells l-1) }\end{array}$ \\
\hline \multicolumn{11}{|c|}{$\left(39^{\circ} 60^{\prime} \mathrm{S}, 169^{\circ} 60^{\prime} \mathrm{W} ; 22\right.$ Jan 2005$)$} \\
\hline $\begin{array}{l}\mathrm{SX} 22 \\
\left(19^{\circ} 60^{\prime} \mathrm{S},\right.\end{array}$ & $\begin{array}{l}28.6 \\
60^{\prime} \mathrm{W} ;\end{array}$ & $\begin{array}{c}35.1 \\
\text { Jan } 20\end{array}$ & 0.09 & $<0.01$ & 0.09 & $1.8 \pm 0.6$ & $13.0 \pm 0.9$ & $11.0 \pm 0.7$ & $12.0 \pm 1.8$ & $120 \pm 25$ \\
\hline
\end{tabular}




\section{Responses of bacteria and viruses to nutrient additions}

In order to examine the responses of bacteria and viruses to nutrient additions, we compared 3 variables among treatments. (1) TdR incorporation rates of bacteria and viruses determined at the end of the incubation for $24 \mathrm{~h}$; these values are regarded as indices of bacterial production and viral production and are denoted hereafter as $\mathrm{BP}_{24}$ and $\mathrm{VP}_{24}$, respectively. (2) Increases in the abundances of bacteria and viruses during the incubation were determined, i.e. (abundance at the end of the incubation for $24 \mathrm{~h}$ )-(abundance at the beginning of the incubation); these values are regarded as indices of numerical responses of bacteria and viruses and are denoted hereafter as $\Delta N_{\mathrm{b}}$ and $\Delta N_{\mathrm{v}}$, respectively. (3) Cell-specific incorporation rates of $\mathrm{TdR}$ by bacteria were determined at the end of the incubation for $24 \mathrm{~h}_{\text {; }}$ these values are regarded as indices of bacterial growth rates and are denoted hereafter as $\mathrm{BG}_{24}$.

At Stn $\mathrm{SX} 18, \mathrm{BP}_{24}$ differed significantly among treatments (ANOVA with a Bonferroni correction, $p<0.001$ ), with much higher (11- to 19-fold) values in the $\mathrm{N}+\mathrm{C}$ and

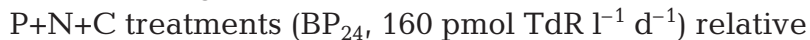
to those in other treatments, including the non-addition

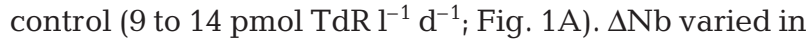
the range of -0.2 to $0.6 \times 10^{8}$ cells $1^{-1}$, which did not differ significantly ( $p>0.05$ ) among treatments (Fig. 1B). $\mathrm{BG}_{24}$ differed significantly $(\mathrm{p}<0.001)$ among treatments, with much greater (12- to 22-fold) values for the $\mathrm{N}+\mathrm{C}$ and $\mathrm{P}+\mathrm{N}+\mathrm{C}$ treatments $\left(62\right.$ to $63 \times 10^{-20} \mathrm{~mol} \mathrm{TdR}$ cell $^{-1} \mathrm{~d}^{-1}$ ) relative to other treatments ( 3 to $5 \times 10^{-20} \mathrm{~mol}$ TdR cell ${ }^{-1} \mathrm{~d}^{-1}$; Fig. 1C). For $\mathrm{VP}_{24}$, the equal-variance criterion was not met for a multiple comparison because of high variability associated with the estimate of mean $\mathrm{VP}_{24}$ in the $\mathrm{P}+\mathrm{N}$ treatment; the coefficient of variation $(\mathrm{CV})$ of $\mathrm{VP}_{24}$ for the $\mathrm{P}+\mathrm{N}$ treatment was $79 \%$, which was much greater than $\mathrm{CVs}$ of $\mathrm{VP}_{24}$ for other treatments (11 to $24 \%$ ). Therefore, in the following comparison of $\mathrm{VP}_{24}$ among treatments, we excluded the estimate for the $\mathrm{P}+\mathrm{N}$ treatment. The result indicates that $\mathrm{VP}_{24}$ varied significantly $(p<0.001)$ among treatments, with much greater (4- to 8-fold) values for the $\mathrm{N}+\mathrm{C}$ and $\mathrm{P}+\mathrm{N}+\mathrm{C}$

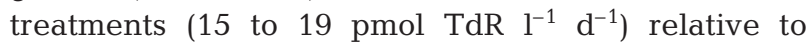
other treatments, including the control $(2.6$ to $3.5 \mathrm{pmol}$ TdR $l^{-1} \mathrm{~d}^{-1}$; Fig. 1D). $\Delta N_{\mathrm{v}}$ varied in the range of -1.5 to $-0.5 \times 10^{8}$ viruses $1^{-1}$, with no significant difference among treatments ( $p>0.05$; Fig. 1E).

The range of $\mathrm{BP}_{24}$ values observed in the Stn SX22

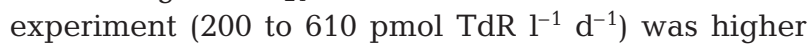
than that in the Stn SX18 experiment (9 to $160 \mathrm{pmol}$ $\operatorname{TdR~} l^{-1} \mathrm{~d}^{-1}$ ), which might be related to higher water temperature at Stn $\mathrm{SX} 22\left(29^{\circ} \mathrm{C}\right)$ than at Stn SX18 $\left(17^{\circ} \mathrm{C}\right)$. At Stn $\mathrm{SX} 22, \mathrm{BP}_{24}$ differed among treatments
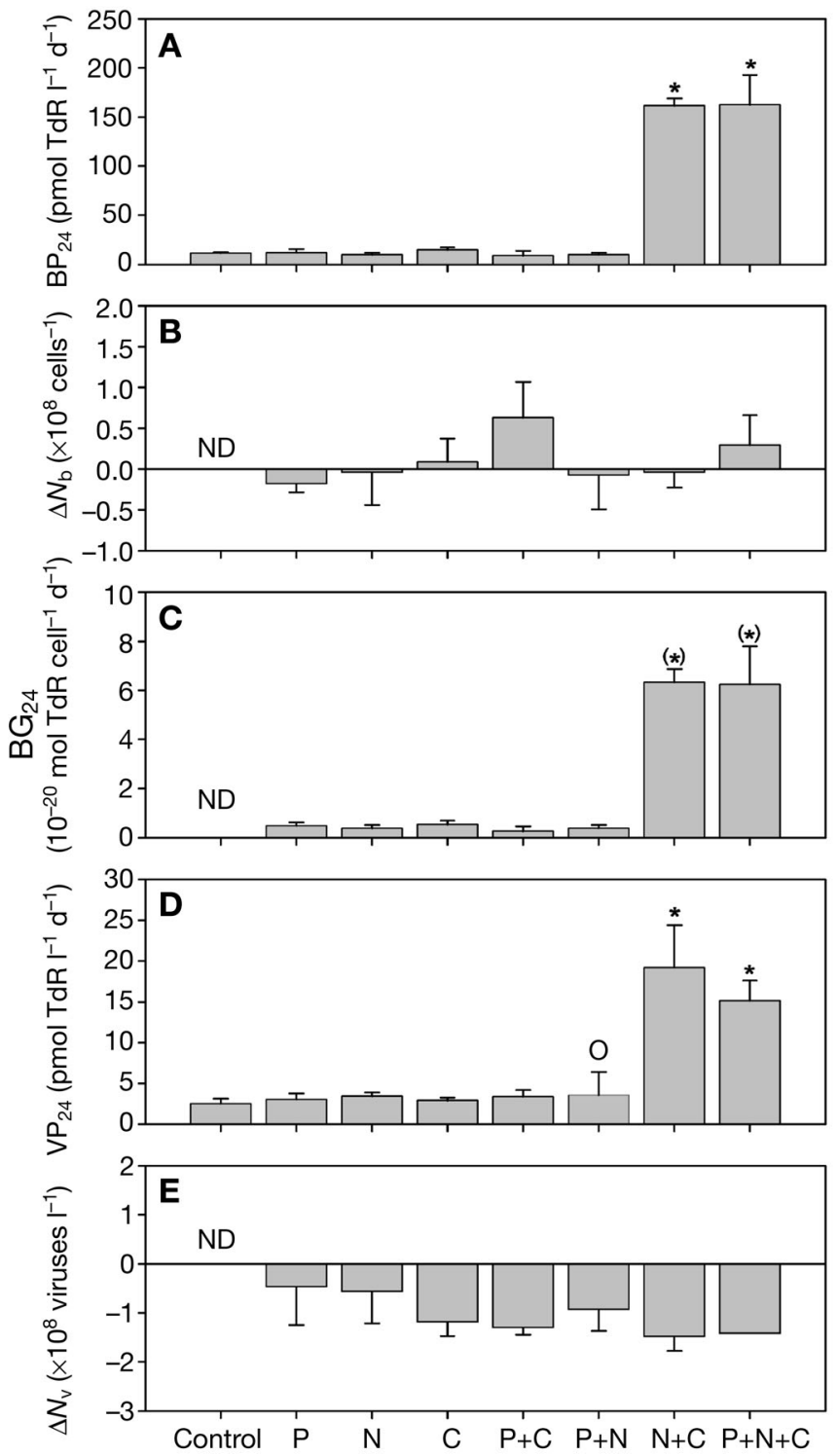

Fig. 1. Responses to nutrient additions of (A) bacterial production $\left(\mathrm{BP}_{24}\right),(\mathrm{B})$ changes in bacterial abundance $\left(\Delta N_{\mathrm{b}}\right),(\mathrm{C})$ cell-specific thymidine (TdR) incorporation rate of bacteria $\left(\mathrm{BG}_{24}\right)$, (D) viral production $\left(\mathrm{VP}_{24}\right)$, and $(\mathrm{E})$ changes in viral abundance $\left(\Delta N_{\mathrm{v}}\right)$ at Stn SX18. Error bars are +SD for triplicate bottles. Multiple comparisons (ANOVA with Bonferroni corrections) among treatments (non-addition control and additions of $\mathrm{P}$ alone, $\mathrm{N}$ alone, $\mathrm{C}$ alone, $\mathrm{P}+\mathrm{C}, \mathrm{P}+\mathrm{N}, \mathrm{N}+\mathrm{C}, \mathrm{P}+\mathrm{N}+\mathrm{C}$ ) were conducted after log transformation of $\mathrm{BP}_{24}, \mathrm{BG}_{24}$, and $\mathrm{VP}_{24}$ in order to fulfill equal variance requirements. ${ }^{*}$ : mean value of a given treatment differs significantly $(p<0.001)$ from that of the non-addition control, except for the following cases. First, $\mathrm{VP}_{24}$ of the $\mathrm{P}+\mathrm{N}$ treatment $(\mathrm{O})$ was excluded from the statistical comparison because the error associated with $\mathrm{VP}_{24}$ for this treatment was anomalously high (see 'Results'). Second, no data were available (ND) for the control of $\Delta N_{b}$, $\mathrm{BG}_{24}$, and $\Delta N_{\mathrm{v}}$, because we lost the sample for counting bacteria and viruses in the control. For these variables, (*): mean values of marked treatments differ significantly $(p<0.001)$ from those of unmarked treatments 


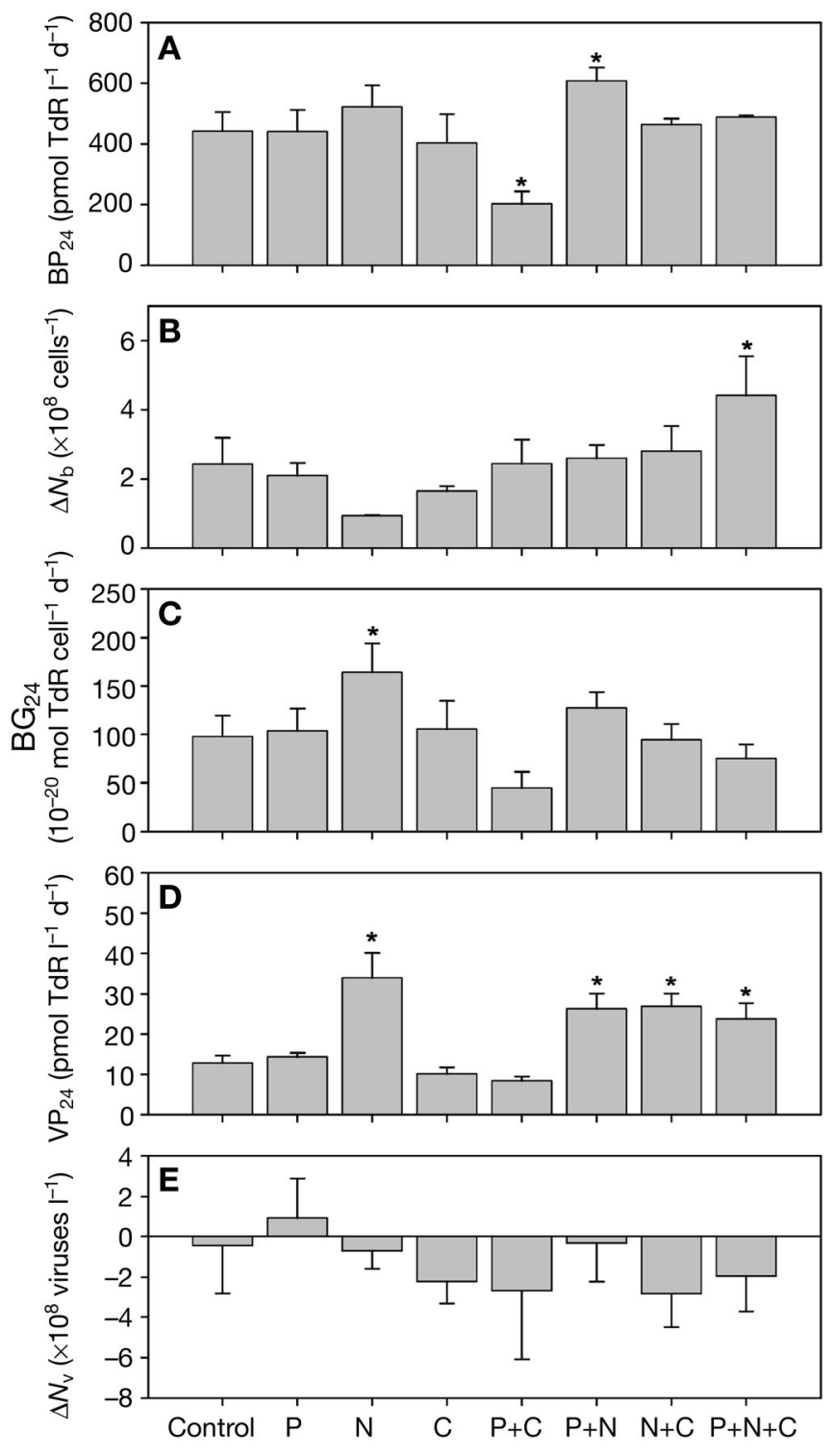

Fig. 2. Responses to nutrient additions of (A) bacterial production $\left(\mathrm{BP}_{24}\right),(\mathrm{B})$ changes in bacterial abundance $\left(\Delta N_{\mathrm{b}}\right),(\mathrm{C})$ cellspecific TdR incorporation rate of bacteria $\left(\mathrm{BG}_{24}\right)$, (D) viral production $\left(\mathrm{VP}_{24}\right)$, and (E) changes in viral abundance $\left(\Delta N_{\mathrm{v}}\right)$ at Stn SX22. Error bars are +SD of estimates derived for triplicate bottles. Multiple comparisons (ANOVA with Bonferroni corrections) among treatments (non-addition control and additions of $\mathrm{P}$ alone, $\mathrm{N}$ alone, $\mathrm{C}$ alone, $\mathrm{P}+\mathrm{C}, \mathrm{P}+\mathrm{N}, \mathrm{N}+\mathrm{C}, \mathrm{P}+\mathrm{N}+\mathrm{C}$ ) were conducted; $*$ : mean value of a given treatment differs significantly $(\mathrm{p}<0.001)$ from that of the non-addition control

( $\mathrm{p}<0.001)$, with either lower $(\mathrm{P}+\mathrm{C}$ treatment, $200 \mathrm{pmol}$

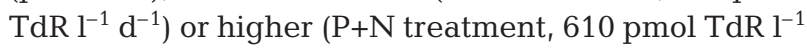
$\mathrm{d}^{-1}$ ) values relative to the control (440 pmol TdR $\mathrm{l}^{-1} \mathrm{~d}^{-1}$ )

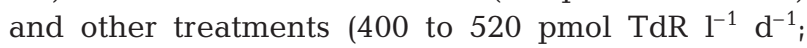
Fig. 2A). $\Delta N_{\mathrm{b}}$ varied in the range of 1.4 to $4.9 \times 10^{8}$ cells $\mathrm{l}^{-1}: \Delta N_{\mathrm{b}}$ in the $\mathrm{P}+\mathrm{N}+\mathrm{C}$ treatment was significantly $(p<0.05)$ higher than corresponding values relative to the control (Fig. 2B). BG $_{24}$ differed significantly $(p<0.05)$ among treatments, with higher values in the $\mathrm{N}$ treatment $\left(160 \times 10^{-20} \mathrm{~mol} \mathrm{TdR} \mathrm{cell}{ }^{-1} \mathrm{~d}^{-1}\right)$ relative to the control $\left(100 \times 10^{-20} \mathrm{~mol} \mathrm{TdR}\right.$ cell $^{-1} \mathrm{~d}^{-1}$; Fig. 2C).

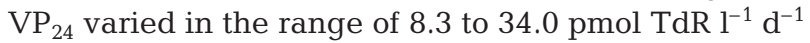
and differed among treatments $(\mathrm{p}<0.001)$. $\mathrm{VP}_{24}$ in the $\mathrm{N}, \mathrm{P}+\mathrm{N}, \mathrm{N}+\mathrm{C}$, and $\mathrm{P}+\mathrm{N}+\mathrm{C}$ treatments were 2- to 3-fold greater than those in the control and other treatments, which varied in the range of 8.3 to $14.0 \mathrm{TdR}^{-1} \mathrm{~d}^{-1}$ (Fig. 2D). $\Delta \mathrm{Nv}$ was in the range of -3.3 to $0.4 \times 10^{8}$ viruses $\mathrm{l}^{-1}$, which did not differ among treatments (p > 0.05; Fig. 2E).

\section{DISCUSSION}

Our study is the first to demonstrate viral responses to nutrient additions in oligotrophic ( $\mathrm{chl} a<0.1 \mu \mathrm{g} \mathrm{l}^{-1}$ ) oceanic environments. The enhancement of viral production $\left(\mathrm{VP}_{24}\right)$ in the $\mathrm{N}+\mathrm{C}$ and $\mathrm{P}+\mathrm{N}+\mathrm{C}$ treatments of the SX18 experiment suggests that viral production was co-limited by $\mathrm{N}$ and $\mathrm{C}$. This response of viral production agreed well with that of bacterial production $\left(\mathrm{BP}_{24}\right)$ and growth $\left(\mathrm{BG}_{24}\right)$ following nutrient additions, indicating that viral production was enhanced because of increasing bacterial growth. Because the numerical response of bacteria $(\Delta \mathrm{Nb})$ to the enrichment was minimal (probably because bacterial growth was balanced by the loss due to HNF bacterivory; Strom 2000), it is unlikely that the enhancement of viral production was due to the increasing encounter probability between host and viruses. The above results are consistent with the hypothesis that viral production depends on the growth of the host (Moebus 1996a,b, Middelboe 2000), which in turn is limited by nutrients in marine environments (Bratbak et al. 1993, Tuomi et al. 1995, Hewson et al. 2001, Williamson \& Paul 2004, Bongiorni et al. 2005).

In contrast, at Stn SX22, we found that viral production $\left(\mathrm{VP}_{24}\right)$ was enhanced in treatments with $\mathrm{N}$ additions $(\mathrm{N}, \mathrm{P}+\mathrm{N}, \mathrm{N}+\mathrm{C}$, and $\mathrm{P}+\mathrm{N}+\mathrm{C})$, whereas bacterial production $\left(\mathrm{BP}_{24}\right)$ and abundance $(\Delta \mathrm{Nb})$ did not display such a trend, except that $\mathrm{BP}_{24}$ in the $\mathrm{P}+\mathrm{N}$ treatment, $\Delta \mathrm{Nb}$ in the $\mathrm{P}+\mathrm{N}+\mathrm{C}$ treatment, and $\mathrm{BG}_{24}$ in the $\mathrm{N}$ treatment were significantly higher than the corresponding values in the other treatments. This uncoupling between bacterial and viral responses to nutrient additions at Stn SX22 may indicate that the induction of prophage production occurred among lysogenic populations of bacteria in response to the alteration of the metabolic status of host cells. In the bacteriophage $\lambda$, it has been suggested that a 'lysogenic decision' occurs toward the mode of lytic phase in response to changes in growth conditions from poor to rich media (Oppenheim et al. 2005). Consistent with this notion, William- 
son et al. (2002) found that prophage induction was occasionally stimulated by $\mathrm{P}$ additions in Tampa Bay, Florida, USA. This led us to hypothesize that the enhanced viral production at Stn SX22 was due to the switching of lysogenic to lytic mode of infection of viruses due to metabolic alterations of bacteria, explaining the attenuation in responses of bacterial production to $\mathrm{N}$ enrichment. This hypothesis is consistent with the proposition that a lysogenic mode of viral infection is common in oligotrophic oceans (Jiang \& Paul 1998). However, further studies are clearly needed to examine the relative importance of lytic infection and lysogeny in oligotrophic waters of the South Pacific.

Some methodological problems should be commented on. We determined viral production using a TdR approach (Noble \& Steward 2001), which has advantages in sensitivity and simplicity over other techniques such as the dilution and the fluorescently labeled virus methods (Noble \& Steward 2001, Helton et al. 2005). The TdR method is particularly suitable for nutrient addition studies in which a large number of samples ( $\mathrm{n}=24$ for each experiment in the present study) must be handled promptly. However, conversion factors that relate TdR incorporation rate to viral production have been poorly constrained, especially in oligotrophic environments (Helton et al. 2005). Although conversion factors may vary depending on viral genome size, $\mathrm{G}+\mathrm{C}$ content, and isotope dilution factors, little is known about variations of these variables in oceanic environments. Given that viruses can use host nucleic acids and that RNA-containing viruses would not be labeled, viral production determined by the TdR method would be too low (Helton et al. 2005). Conversely, the TdR method might overestimate viral production because of the inclusion of non-specifically labeled components in the fraction of viral DNA. It has been suggested that TdR catabolism can cause non-specific labeling of bacterial components (e.g. proteins) (Brittain \& Karl 1990), which potentially results in the production of ${ }^{3} \mathrm{H}$-labeled colloidal debris in the $<0.2 \mu \mathrm{m}$ fraction. To minimize this effect, we treated the samples with proteases (see 'Materials and methods'). However, proteins and DNA coated by liposome-like particles might not be digested by enzymes (Nagata \& Kirchman 1997). Because of the above reasons, the data on viral production obtained using the TdR method in oligotrophic systems should be interpreted cautiously. However, biases associated with the above factors are probably not systematic with regard to the treatments used in this study (i.e. nutrient additions). Thus, although the accuracy of the estimates of viral production determined by the TdR method remains to be ascertained by future studies, we consider that our conclusions concerning patterns in responses (i.e. relative values) of viral production to nutrient additions are valid.

Our results suggesting that viral production is limited by either $\mathrm{N}$ (Stn SX22 experiment) or N+C (Stn SX18 experiment) but not by P (both Stn SX22 and SX18 experiments) contrast the results obtained in previous enrichment studies, which have generally suggested that viral production is limited by $\mathrm{P}$ in coastal and neritic waters (Bratbak et al. 1993, Tuomi et al. 1995, Williamson \& Paul 2004). Bratbak et al. (1993) suggested that viral production may be more sensitive to $\mathrm{P}$ than $\mathrm{N}$ limitation because the nucleic acid-to-protein ratios (hence P:N ratios) of viruses are high. However, it has been demonstrated that viruses use host nucleotides for the synthesis of viral DNA (Wikner et al. 1993). This mechanism could facilitate effective scavenging of $\mathrm{P}$ resources from the host, alleviating $\mathrm{P}$ limitation of viral production. Therefore, it is probably not surprising that viral production is limited by the availability of $\mathrm{N}$ rather than $\mathrm{P}$ to be used for the synthesis of capsid protein. However, the mode of stoichiomeric regulations of virus-host systems under nutrient-limited conditions is poorly understood (Wikner et al. 1993). It remains to be seen if $\mathrm{N}$ limitation of viral production is widespread in oligotrophic open waters of the Pacific where $\mathrm{N}$ is chronically depleted.

In both the Stn SX18 and SX22 experiments, despite significant effects of nutrient additions to viral production, viral abundance $\left(\Delta N_{\mathrm{v}}\right)$ showed no consistent trends, being close to 0 or negative in most cases. One hypothesis to explain this observation is that the loss of viruses occurred during the incubation at rates comparable to or exceeding those of viral production. To examine the extent and variations of viral loss, the rate of the loss of viruses $\left(L\right.$, viruses $\left.\mathrm{l}^{-1} \mathrm{~d}^{-1}\right)$ was calculated as follows:

$$
L=\rho-\left(N_{24}-N_{0}\right)
$$

where $\rho$ is the production rate of viral particles (viruses $\mathrm{l}^{-1} \mathrm{~d}^{-1}$ ) averaged for samples collected at the beginning and at the end of the incubation, and $N_{24}$ and $N_{0}$ are viral abundances at the end and at the beginning of incubation, respectively. To convert the incorporation rate of TdR to $\rho$, we used a conversion factor of $6 \times 10^{20}$ viruses mol-TdR ${ }^{-1}$ (Steward et al. 1992). Results indicate that substantial losses occurred in both Stn SX18 $\left(1\right.$ to $6 \times 10^{9}$ viruses $\mathrm{l}^{-1} \mathrm{~d}^{-1}$ ) and SX22 ( 7 to $14 \times 10^{9}$ viruses $\mathrm{l}^{-1} \mathrm{~d}^{-1}$ ) experiments. By using all data collected from the 2 experiments, we found that viral loss rates are positively correlated with bacterial production, which varied by 70 -fold (9 to $610 \mathrm{pmol}$ TdR $\mathrm{l}^{-1} \mathrm{~d}^{-1}$ ) across experiments and among treatments (Fig. 3); $89 \%$ of variations in viral loss rates were accounted for by bacterial production. Note that the above calculation is based on an assumption that viral production is 


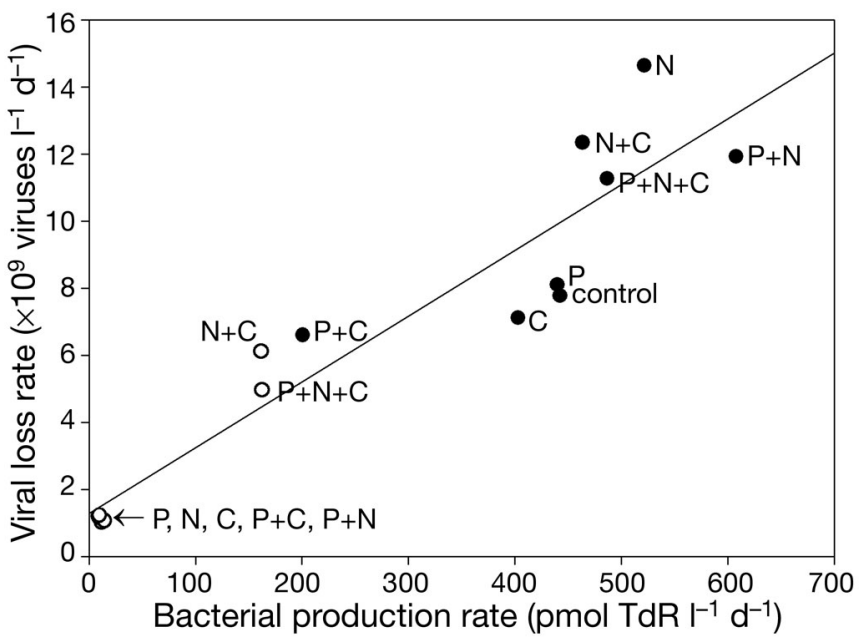

Fig. 3. Relationship between bacterial production rate (TdR incorporation rate) and viral loss rate. Individual plots represent the data obtained for individual treatments of the Stn SX18 $(\bigcirc)$ and Stn SX22 (๑) experiments. The linear regression equation is: viral loss $\left(10^{9}\right.$ viruses $\left.\mathrm{l}^{-1} \mathrm{~d}^{-1}\right)=0.02 \times$ bacterial production $\left(\mathrm{TdR}\right.$ pmol $\left.\mathrm{l}^{-1} \mathrm{~d}^{-1}\right)+1.30 ; \mathrm{n}=15, \mathrm{r}^{2}=0.89, \mathrm{p}<0.001$

related to the ${ }^{3} \mathrm{H}$-TdR incorporation rate with a fixed conversion factor. However, in their study on ${ }^{32} \mathrm{P}$ tracer fluxes in a virus-bacteria model, Wikner et al. (1993) suggested that the isotope dilution decreases (hence viruses with higher specific activities are produced) with increasing specific growth rate of bacteria. If this model-based prediction generally applies to viral-host communities in oligotrophic open waters, the variation in the isotope dilution might explain, to a certain extent, the pattern depicted in Fig. 3. This possibility should be examined in future studies.

Several factors could contribute to the loss of viruses in marine waters. These factors include (1) enzymatic degradation and adsorption to colloidal substances (Noble \& Fuhrman 1997), (2) grazing by HNF (Gonzalez \& Suttle 1993), (3) scavenging by settling particles (Proctor \& Fuhrman 1991), and (4) solar irradiance (Suttle \& Chen 1992), although the latter 2 factors could be discounted in our incubation experiments. Our results showing that viral loss rates increase with increasing bacterial production suggest that enzymes and colloidal particles are more abundantly produced when bacterial production is high. Alternatively, high bacterial production may result in high grazing activities by flagellates, which in turn can consume viruses (Gonzalez \& Suttle 1993). Regardless of the exact mechanisms, our results suggest that viral loss might be closely coupled with bacterially mediated processes. We also point out that effects of nutrient additions to viruses could be largely underestimated if only viral abundance is examined as a response variable.
To conclude, our data support the hypothesis that nutrients limit viral production in oligotrophic surface waters of the South Pacific, with element(s) of deficiency being $\mathrm{N}$ or $\mathrm{N}+\mathrm{C}$. Enhancement of viral production was coupled with bacterial growth rather than abundance, although our results also suggest that $\mathrm{N}$ addition might induce prophage production with minimal responses in bacterial production. Several studies have found that bacterial production is enhanced by additions of $\mathrm{NH}_{4}$ and glucose (but usually not by the addition of $\mathrm{NH}_{4}$ alone) in oceanic regions (Kirchman 1990, Cherrier et al. 1996, Kirchman \& Rich 1997, Church et al. 2000), but these studies did not examine responses of viral production. Generally, it is predicted that gross growth efficiency (GGE) of bacteria increases with increasing availability of N (Goldman et al. 1987), leading to the increase in efficiencies of the transfer of carbon from dissolved organic matter (DOM) to higher trophic levels via a DOM-bacteria pathway. However, if the response of bacteria to $\mathrm{N}$ (or $\mathrm{N}+\mathrm{C}$ ) addition is generally accompanied by viral responses, as we have suggested here, the enhancement by nutrients of bacterial GGE can be largely compensated by the enhancement of the 'viral shunt' (Fuhrman 1999, Wilhelm \& Suttle 1999), a possibility that should be examined in future studies. Despite increasing viral production due to nutrient additions, we failed to detect responses in the abundance of viruses, which appears to be explained by close coupling of viral loss and bacterial production. Further studies are required to examine in greater detail the mechanisms underlying coupling and uncoupling of bacterial production, viral production, and viral loss in marine systems.

Acknowledgements. We thank T. Yokokawa for support during the experiments, and the captain, officers, and crew of RV 'Hakuho-Maru' for logistical support. This study was conducted as part of the Dynamics of the Ocean Biosystems (DOBIS) project (Ministry of Education, Culture, Sports, Science, and Technology [MEXT] Grant-in-Aid for Creative Basic Research, 12NP0201). Financial support was also provided by the 21st Century Centers of Excellence (COE) program (A14) of Kyoto University and by Japan Society for the Promotion of Science (JSPS) grants (17201004 and 18631007) awarded to T.N.

\section{LITERATURE CITED}

Bongiorni L, Magagnini M, Armeni M, Noble RT, Danovaro R (2005) Viral production, decay rates, and life strategies along a trophic gradient in the North Adriatic Sea. Appl Environ Microbiol 71:6644-6650

Bratbak G, Egge JK, Heldal M (1993) Viral mortality of the marine alga Emiliania huxleyi (Haptophyceae) and termination of algal blooms. Mar Ecol Prog Ser 93:39-48

Brittain AM, Karl DM (1990) Catabolism of tritiated thymidine by aquatic microbial communities and incorporation of tritium into RNA and protein. Appl Environ Microbiol 56: $1245-1254$ 
Carlson CA, Ducklow HW (1996) Growth of bacterioplankton and consumption of dissolved organic carbon in the Sargasso Sea. Aquat Microb Ecol 10:69-85

Cherrier J, Bauer JE, Druffel ERM (1996) Utilization and turnover of labile dissolved organic matter by bacterial heterotrophs in eastern North Pacific surface waters. Mar Ecol Prog Ser 139:267-279

Church MJ, Hutchins DA, Ducklow HW (2000) Limitation of bacterial growth by dissolved organic matter and iron in the Southern Ocean. Appl Environ Microbiol 66:455-466

Fuhrman JA (1999) Marine viruses and their biogeochemical and ecological effects. Nature 399:541-548

Goldman JC, Caron DA, Dennett MR (1987) Regulation of gross growth efficiency and ammonium regeneration in bacteria by substrate C:N ratio. Limnol Oceanogr 32:1239-1252

Gonzalez JM, Suttle CA (1993) Grazing by marine nanoflagellates on viruses and virus-sized particles: ingestion and digestion. Mar Ecol Prog Ser 94:1-10

Helton RR, Cottrell MT, Kirchman DL, Wommack KE (2005) Evaluation of incubation-based methods for estimating virioplankton production in estuaries. Aquat Microb Ecol 41:209-219

Hewson I, O'Neil JM, Fuhrman JA, Dennison WC (2001) Virus-like particle distribution and abundance in sediments and overlying waters along eutrophication gradients in two subtropical estuaries. Limnol Oceanogr 46: $1734-1746$

Hoppe HG, Gocke K, Koppe R, Kraus G (2006) Changing bacterioplankton growth characteristics on a large spatial scale: oligotrophic versus mesotrophic ocean. Mar Ecol Prog Ser 323:21-33

Jiang SC, Paul JH (1998) Significance of lysogeny in the marine environment: studies with isolates and a model of lysogenic phage production. Microb Ecol 35:235-243

Kirchman DL (1990) Limitation of bacterial growth by dissolved organic matter in the subarctic Pacific. Mar Ecol Prog Ser 62:47-54

Kirchman DL (2001) Measuring of bacterial biomass production and growth rates from leucine incorporation in natural aquatic environment. In: Paul JH (ed) Methods in microbiology, Vol 30. Academic Press, San Diego, CA, p 227-237

Kirchman DL, Rich JH (1997) Regulation of bacterial growth rates by dissolved organic carbon and temperature in the equatorial Pacific Ocean. Microb Ecol 33:11-20

Longhurst A (1998) Ecological geography of the sea. Academic Press, San Diego, CA

Lymer D, Vrede K (2006) Nutrient additions resulting in phage release and formation of non-nucleoid-containing bacteria. Aquat Microb Ecol 43:107-112

Middelboe M (2000) Bacterial growth rate and marine virushost dynamics. Microb Ecol 40:114-124

Moebus K (1996a) Marine bacteriophage reproduction under nutrient-limited growth of host bacteria. I. Investigations with six phage-host systems. Mar Ecol Prog Ser 144:1-12

Moebus K (1996b) Marine bacteriophage reproduction under nutrient-limited growth of host bacteria. II. Investigations with six phage-host systems [H3:H3/1]. Mar Ecol Prog Ser 144:13-22

Nagata T, Kirchman DL (1997) Roles of submicron particles and colloids in microbial food webs and biogeochemical cycles within marine environments. Adv Microb Ecol 15:81-103

Noble RT (2001) Enumeration of viruses. In: Paul JH (ed) Methods in microbiology, Vol 30. Academic Press, San Diego, CA, p 43-51
Noble RT, Fuhrman JA (1997) Virus decay and its causes in coastal waters. Appl Environ Microbiol 63:77-83

Noble RT, Fuhrman JA (1998) Use of SYBR Green I for rapid epifluorescence counts of marine viruses and bacteria. Aquat Microb Ecol 14:113-118

Noble RT, Steward GF (2001) Estimating viral proliferation in aquatic samples. In: Paul JH (ed) Methods in microbiology, Vol 30. Academic Press, San Diego, CA, p $67-83$

Oppenheim AB, Kobiler O, Stavans J, Court DL, Adhya S (2005) Switches in bacteriophage lambda development. Annu Rev Genet 39:409-429

Proctor LM, Fuhrman JA (1991) Roles of viral infection in organic particle flux. Mar Ecol Prog Ser 69:133-142

Rivkin RB, Anderson MR (1997) Inorganic nutrient limitation of oceanic bacterioplankton. Limnol Oceanogr 42:730-740

Sherr BF, Sherr EB (1983) Enumeration of heterotrophic microprotozoa by epifluorescence microscopy. Estuar Coast Shelf Sci 16:1-7

Steward GF, Wikner J, Smith DC, Cochlan WP, Azam F (1992) Estimation of virus production in the sea: I. Method development. Mar Microb Food Webs 6:57-78

Steward GF, Smith DC, Azam F (1996) Abundance and production of bacteria and viruses in the Bering and Chukchi Seas. Mar Ecol Prog Ser 131:287-300

Strom SL (2000) Bacterivory: interactions between bacteria and their grazers. In: Kirchman DL (ed) Microbial ecology of the oceans. Wiley-Liss, New York, p 351-386

Suttle CA, Chen F (1992) Mechanisms and rates of decay of marine viruses in seawater. Appl Environ Microbiol 58: $3721-3729$

Thingstad T (2000) Elements of a theory for the mechanisms controlling abundance, diversity, and biogeochemical role of lytic bacterial viruses in aquatic systems. Limnol Oceanogr 45:1320-1328

Tuomi P, Kuuppo P (1999) Viral lysis and grazing loss of bacteria in nutrient- and carbon-manipulated brackish water enclosures. J Plankton Res 21:923-937

Tuomi P, Fagerbakke KM, Bratbak G, Heldal M (1995) Nutritional enrichment of a microbial community: the effects on activity, elemental composition, community structure and virus production. FEMS Microbiol Ecol 16:123-134

Weinbauer MG (2004) Ecology of prokaryotic viruses. FEMS Microbiol Rev 28:127-181

Weinbauer MG, Christaki U, Nedoma A, Šimek K (2003) Comparing the effects of resource enrichment and grazing on viral production in a meso-eutrophic reservoir. Aquat Microb Ecol 31:137-144

Wikner J, Vallino JJ, Steward GF, Smith DC, Azam F (1993) Nucleic acids from the host bacterium as a major source of nucleotides for three marine bacteriophages. FEMS Microbiol Ecol 12:237-248

Wilhelm SW, Suttle CA (1999) Viruses and nutrient cycles in the sea. BioScience 49:781-788

Williamson SJ, Paul JH (2004) Nutrient stimulation of lytic phage production in bacterial populations of the Gulf of Mexico. Aquat Microb Ecol 36:9-17

Williamson SJ, Houchin LA, McDaniel L, Paul JH (2002) Seasonal variation in lysogeny as depicted by prophage induction in Tampa Bay, Florida. Appl Environ Microbiol 68:4307-4314

Wilson WH, Turner S, Mann NH (1998) Population dynamics of phytoplankton and viruses in a phosphate-limited mesocosm and their effect on DMSP and DMS production. Estuar Coast Shelf Sci 46:49-59 